\title{
The Development of Multilingual EFL \\ Teachers' Professional Vision and Practical \\ Teaching Capabilities in Video-Based \\ Surroundings - Do Language Learning \\ Biographies Have an Impact?
}

\author{
Heike Niesen \\ Goethe University Frankfurt/Main
}

\begin{abstract}
The present paper draws on research findings about ESL and EFL teachers' language learning biographies. More precisely, the paper draws on major insights from prior research that investigated the effects teachers' languages, other than the target language, English, have on their professional identities and development. The question is answered if existing research findings hold in German video-based training contexts that aim to develop pre-service teachers' multilingual-sensitive Professional Vision and practical teaching capabilities. Questionnaire-based data $(n=39)$ indicates that participants rely on their language (learning) biographies when planning and reflecting on multilingual-sensitive EFL teaching videos, albeit with varying degrees. Further, participants tend to employ specific languages for particular purposes.
\end{abstract}

Keywords: Professional Vision, language (learning) biographies, multilingual-sensitivity

Throughout the past decade actors involved in foreign language teacher education have addressed the challenges and uncertainties that have arisen as a result of an increasing heterogeneity in schools (cf., e.g. Banks et al., 2005; Lightbown \& Spada, 2013). In this context, pupils' multilingualism has been recognized as a constitutive part of heterogeneity (Trautmann, 2010; Trautmann \& Wischer, 2011; Ziegler, 2013). Pupils' multilingualism has been considered as both a prerequisite for and goal of foreign language teaching (Hufeisen \& Neuner, 2005), i.e. teachers are to notice, value and use the languages their pupils bring to class to enrich and foster learning a foreign or second language and to ensure that pupils develop an awareness of multilingualism resulting in the acquisition of various languages throughout lifelong learning (Europarat, 2001; European Commission, 2015). A solid amount of research has investigated multilingualism and its implications for English language teaching and learning, ranging from conceptually and theoretically-oriented monographs (Cenoz \& Gorter, 2014; Conteh \& Meier, 2014; Jessner, 2006; May, 2014) to rather practical teacher guidelines of how to deal with multilingual learning groups (Abney \& Krulatz, 2015; Milambiling, 2011; Schecter \& Cummins, 2003).

Undoubtedly, this research is of indispensable value to equip pre- and in-service EFL and ESL teachers with both theoretical and practical insights into pupils' multilingualism and ways it may be employed to enrich teaching and learning processes. At the same time, however, research that explicitly focuses on teachers' multilin- 
64 gualism as a phenomenon worth considering in teacher education is relatively scarce compared to the efforts undertaken to understand and use pupils' multilingualism in foreign language learning settings. The present article aims to address this gap. German pre-service EFL teachers' multilingualism is put into focus by examining the role their languages, other than the target language English, might play when planning and reflecting on EFL lessons that have been designed in such a way as to adopt to a multilingual learning group. A detailed account of the university classes participants attended is offered, both of which were conducted at Goethe University Frankfurt/Main and were classes aimed to develop students' Professional Vision and practical teaching capabilities. Hereafter, the insights gained through questionnaire implementation and analyses are portrayed and embedded within existing research findings.

\section{Video-based development of teachers' Professional Vision (PV)}

\subsection{What is PV?}

In the context of teacher education or teachers' professional development, the notion of Professional Vision (Goodwin, 1994) has been frequently addressed throughout the past decade (Sherin, 2004, 2007; Sherin \& van Es, 2002; Sherin \& Han, 2004). Professional Vision (henceforth, PV) is generally exemplified as "the ability to observe what is happening in a classroom" (Sherin, 2007; cf. also Borko et al., 2008). The development of PV demands teachers' active cognitive involvement in two processes, namely "selective attention" and "knowledge-based reasoning" (Sherin \& van Es, 2009; van Es \& Sherin, 2008). Whereas the former is a prerequisite for teachers capacity to "notice"1 classroom events "relevant to learning" (Seidel et al., 2011; Sherin, 2007, respectively), the latter aims at an in-depth examination of these classroom events on various levels:

Once they have noticed classroom events, teachers begin to reason about those events based on their professional knowledge and understanding of teaching and learning. Three aspects of this reasoning process have been distinguished [...]: first, the ability to describe precisely what has been noticed; second, higher-order processes in which observed classroom observations are linked to prior knowledge and understanding of teaching and learning; third, knowledge-based reasoning processes in which the link between the event and the theory is used to evaluate and predict what might happen as a result of the observed situation. (Seidel et al., 2011)

The analytic steps involved in PV have frequently been associated with a teacher's "reflective capability" (Reed et al., 2002), which, in turn, goes back to

1 Alternative terms such as "call out" (Frederiksen et al., 1998), or "stopping point" (Jacobs \& Morita, 2002) have been suggested to describe "the process by which teachers identify what is relevant in a classroom situation" (Seidel et al., 2011). 
Schön's concept of the "reflective practitioner" and his notion of "reflection-on-action" (Schön, 1983; Zeichner \& Liston, 1987). While "reflection-in-action", just like "professional vision in-action" (Sherin et al., 2008), occurs in the process of teaching, "reflection-on-action" and "reflection-for-action" comprise teachers' reflective activities when viewing their teaching and using their insights for the planning of their teaching, respectively (Farrell, 1998, p. 13).

Needless to say, attempts to enhance a multi-layered and highly complex competence such as teachers' PV demand carefully designed professional development programs. Numerous of such programs rely on the implementation of teaching videos as a tool which lends itself well to the achievement of this aim, as shown in the next section.

\subsection{Video-based development of PV}

The positive effects the analyses of teaching videos can have on teachers' professional development in a general sense shall not be elaborated in detail here since prior research has done so extensively (Brophy, 2004; Borko et al., 2008; Baecher et al., 2013; Kleinknecht et al., 2014; Rosaen et al., 2008; Zhang et al., 2011). It is suffice to say that teaching videos help to "capture the richness and complexity of elusive classroom practice" (Zhang et al., 2011, p. 454) and enable teachers "to enter the world of the classroom without having to be in the position of teaching in-the-moment" (Sherin, 2004, p. 13). In other words, "video affords the luxury of time" (Sherin, 2004, p. 13), thereby putting teachers in the position to be engaged in "specific and detailed noticing" (Rosaen et al., 2008, p. 357). Besides these rather general insights, research has also uncovered the role video analyses may play in terms of propelling teachers' PV as defined in the previous passage. The first to mention amongst those who explicitly addressed video-based PV development are Sherin and colleagues (Sherin \& van Es, 2009; Sherin \& Han, 2004) who emphasize that through the use of videos, teachers "learned to attend to particular kinds of events that happen in a classroom and [...] to reason about these events in particular ways" (Sherin \& Han, 2004, p. 179). The authors further "suggest that it can be productive to consider the learning that takes place as teachers interact around video as helping to change teachers' professional vision" (Sherin \& van Es, 2009, p. 33). This view is supported by researchers who examined the impact different kinds of teaching videos have on the development of teachers' PV (Hellermann et al., 2015; Kleinknecht \& Schneider, 2013; Seidel et al., 2011).

In sum, researchers generally agree that teaching videos can serve as appropriate tools to foster teachers' PV as a constitutive part of their professional development. At this point, one might rightfully ask whether and to what extent the development of PV translates into teachers' practical teaching capabilities; a question addressed in the following section. 
Support for the assumption that an increase in PV has a positive impact on practical teaching is provided by various researchers (cf. e.g. Reed, Davis, \& Nyabanyaba, 2002), although research on this topic is still relatively scarce. Kleinknecht and Schneider (2013) state "it is likely that the ability to analyze situations is a prerequisite for the ability to act adaptively in these situations" (Kleinknecht \& Schneider, 2013, p. 14). This view is underlined by researchers who put more explicit weight on the role teachers' analytic capabilities have on their teaching practices. For instance, Krammer and Hugener (2014) argue that "the ability to analyze teaching situations is seen as a predominant prerequisite for successful teaching" (Krammer \& Hugener, 2014, p. 25; trans.) and, in addition, that "findings about the interrelation of teaching-related analytic competencies and effective teaching confirm the importance of this ability" (Krammer \& Hugener, 2014, p. 25; trans.).

\section{Teachers' language (learning) biographies (LLBs)}

The majority of studies investigating the impact English teachers' language biographies have on their profession were conducted in ESL contexts (Amin, 2001; Ellis, 2004; Garvey \& Murray, 2004; Moloney \& Giles, 2015; Safford \& Kelly, 2010). Hence, what all these studies have in common is the fact that they investigated teachers' language backgrounds in English teaching contexts which share English as the official language such as in Australia (Ellis, 2004; Garvey \& Murray, 2004; Moloney \& Giles, 2015) or Great Britain (Safford \& Kelly, 2010). Teachers in educational contexts like this are either Native Speakers (NS) of the target language English or they have learned English as a second or foreign language themselves. The latter are commonly referred to as "Non-Native-Speaking (NNS)" language professionals or "Non-Native English Speaking Teachers (NEST)" (Garvey \& Murray, 2004; Safford \& Kelly, 2010). Although many researchers draw on this basic distinction, some offer a more complex classification of teachers' language backgrounds. In answering the question "whether language learning experience is a contributor to ESL teachers' professional knowledge", Ellis (2004) provides a threefold distinction between "non-native teachers of English who are bi-/multilingual by definition", "native-speaker teachers who are bi-/multilingual" and "native-speaker teachers who are monolingual" (Ellis, 2004, p. 93). To a certain extent, Ellis' findings diminish the dominance of the NS NNS distinction:

In terms of linguistic knowledge relevant to ESL teaching, the multilingual teachers, both native and non-native speakers of English, appeared to have more in common with each other than with the monolingual teachers. Experience of language learning, then, seemed to be a more important factor here than did native/non-native speaker status. (Ellis, 2004, p. 96) 
Bi- or multilingual teachers' advantages rooted in personal language learning experiences and not only included knowledge of "their own preferred learning styles and strategies" which, in turn, helped them to understand "how students differ in their approaches to learning" (Ellis, 2004, p. 98) and to adopt their teaching to these differing needs, they also empowered teachers to compare languages, thereby showing pupils how languages are related on phonological, syntactic, lexical or pragmatic levels (cf. Ellis, 2004). Further, immigrant bi- or multilingual teachers turned out to be flexible language users for they frequently move between their home languages and English, a phenomenon "manifested [...] in their everyday experience of code switching, sometimes according to relationships, [or] to domains of use, as between home and work, and sometimes according to topic" (Ellis, 2004, p. 97). Teachers with the additional experience of having learned English as a foreign or second language appeared to perceive themselves as (successful) learners, and, as such, could function as a "model" and build "solidarity" with their pupils, whom they may teach more "credibly" than other teachers, especially since they have "experienced the same phenomen[a] in the same language as the students are struggling with" (Ellis, 2004, p. 98). Finally, Ellis carefully emphasizes that different kinds of language learning experiences may form a rich basis bi- or multilingual teachers can draw upon, depending on the contexts they have learned their languages in:

If we consider the distinction which Wallace (1991) makes between 'received knowledge' from formal education and 'experiential knowledge' from one's own experience, [...] it seems reasonable to conjecture that those who have the experience of becoming multilingual and multicultural will have a richer base of knowledge, beliefs and insights on which to reflect and to inform their practice than those who do not. (Ellis, 2004, p. 103)

The findings obtained by Ellis' study are largely in line with the one conducted by Garvey and Murray (2004) within which the multilingual teachers involved were classified as "NESTs", i.e. they had all learned English in formal contexts. Drawing on Ellis (2002) and Lortie (1975), the authors also underline the impact this (formal) language learning experience known as "apprenticeship of observation" (Garvey \& Murray, 2004) can have on teachers' own practice. Doing so, they go a step further than Ellis by showing that teachers may either adopt or renounce the teaching approaches and strategies they witnessed as learners of English (cf. Garvey \& Murray, 2004). In the former case, teachers "show empathy with students based on their own experience of learning English" (Garvey \& Murray, 2004, p. 10), a factor which also manifests itself in teachers' ability to "foresee" and "predict" pupils' potential learning difficulties clustering around phonological and lexical language features (Garvey \& Murray, 2004, p. 10). Likewise, teachers' empathy with students is stressed by Safford and Kelly (2010) who argue, "multilingual student teachers possess metalinguistic awareness about their pupils' learning needs" (Safford \& Kelly, 2010, p. 407). They illustrate this with an example of one of the participating teachers' comments: “I can see things from [the pupils'] points of view, what they 
might be thinking in their other languages. It's empathetic, really. Sometimes when I'm reading their work I can tell how they're thinking, because I've made the same mistakes" (Safford \& Kelly, 2010, p. 407). The authors suggest the expression "mirror participants" equipped with "insider knowledge" and a "subtle understanding" of their pupils to describe multilingual teachers who are, however, prevented from using their "linguistic and cultural capital" due to monolingual teaching and learning surroundings (Safford \& Kelly, 2010, p. 401, 408). Referring to Clyne (2008), Moloney and Giles (2015) strengthen this criticism arguing that a "monolingual mindset may continue to be an 'impediment to the development of plurilingual potential'" (Moloney and Giles, 2015, p. 125), i.e. in largely ignoring multilingual teachers' linguistic and cultural resources teacher education sites such as universities and schools prevent these teachers from unfolding their "integrated professional identit[ies]" which cover "empathy" with language learners, "metalinguistic abilit[ies]" and "model" functions:

Findings illustrate that plurilingual PSTs ${ }^{2}$ move with flexibility across languages and cultures, crossing boundaries between their homes, communities and networks. They are comfortable with difference, and use metalinguistic skills to communicate across difference. They are willing [...] to have the chance to speak to students or parents in their language [...]. They know they can contribute to student wellbeing and success through empathy [...], and by playing a positive role in supporting student learning. (Moloney \& Giles, 2015, p. 135)

As mentioned before, the studies discussed so far were conducted in ESL contexts. A noteworthy exception which does not draw on the NS-NNS distinction is provided by Otwinowska (2014) who investigated the level of Polish EFL teachers' "plurilingual awareness" (Otwinowska, 2014, p. 97) in relation to a number of factors, amongst them the number of languages teachers have at their command. According to the author, "plurilingual awareness" goes beyond "traditional training of language teachers" (Otwinowska, 2014, p. 97) in that it comprises

1. cross-linguistic and metalinguistic knowledge;

2. knowledge about adopting a plurilingual approach in the classroom;

3. psycholinguistic knowledge of individual learner differences that facilitate learning. (Otwinowska, 2014, p. 101)

Further, "plurilingual awareness" is defined as a prerequisite for teachers' ability to implement plurilingual-sensitive EFL teaching and learning with the aim to further develop EFL learners' “individual multilingualism” by taking "advantage of [pupils'] previous learning experiences and the knowledge of languages they already possess" (Otwinowska, 2014, p. 100f.). All participating teachers were native speakers of Polish. Hence, teachers were "bilingual" at any rate, or "multilingual" if they knew languages in addition to Polish and English, albeit at varying levels of competence.

2 Pre-service teachers 
Whereas the hypothesis that the mere number of languages at teachers' disposal determines their level of "plurilingual awareness" per se could not be confirmed, it was shown that multilingual teachers obtain a higher level of "plurilingual awareness" than bilingual ones if their language competencies in the languages known were at least intermediate (cf. Otwinowska, 2014).

\section{Teachers' LLBs in multilingual-sensitive (MS) development seminars}

\subsection{Outline and objectives of the courses}

The previous sections have addressed two fields, namely the development of teachers' PV via teaching video analyses and the potential advantages multilingual EFL teachers' have over monolingual ones due to their rich language (learning) biographies, which seem rather unconnected at first glance. The following sections combine these two fields in such a way as to investigate whether (and if, to what extent) German EFL pre-service teachers' language (learning) biographies may have an impact on the development of their PV and practical teaching capabilities in a video-based learning context. Throughout the winter term of 2015/16 two seminars addressing the development of EFL pre-service teachers' PV were held at Goethe University Frankfurt/Main. Both seminars ran for 13 weeks with weekly sessions of 90 minutes. The primary aim was to develop pre-service teachers' Professional Vision and their practical teaching competencies in heterogeneous EFL classes. To achieve this aim, students were introduced to the concept of multilingualism as a constitutive part of EFL learners' heterogeneity, as well as to basic assumptions and approaches put forward by multilingual-sensitive teaching pedagogy/didactics and third language leasing (e.g. Cummins, 2005; Jessner, 2006; Hufeisen \& Neuner, 2005). Students were to design mini lessons (micro-teachings) of approximately 20 minutes for an imaginary ${ }^{3} \mathrm{EFL}$ class in groups of four to five people. The challenge here was to plan 'lessons' which take "pupils'" diverse linguistic backgrounds into account, i.e. to include the languages they have at their command in such a way as to facilitate EFL teaching and learning. The mini lessons were held and video-recorded during the seminars and the students participated by acting as "teachers" and "pupils". To make the heterogeneity of the imaginary class more concrete, role cards were designed by the instructor, each of which exemplified a "pupil's" language background, learning difficulties and relation to his or her peers. The role cards remained the same throughout every seminar. An example may serve to illustrate this point:

3 Unfortunately, it was not possible for participants to implement their mini lessons in authentic classrooms at this point in time. 
Table 1 Micro-teaching role card

Role card "Ahmed"

- L1: Arabic (average language skills)

- L2s: German (writing and speaking problems), English (pronounces words as written, often omits the verb "to be" and the auxiliary "do" $\rightarrow$ *What she eating/*Where she is?, problems understanding new texts and remembering new vocabulary

- well-integrated in class, eager to learn, aware of his learning problems $\rightarrow$ frequently talks to his neighbour peers in a mixture of German and Arabic to negotiate meaning

The participants who acted as "pupils" played their roles according to the role cards. After each session, the recorded mini lessons were provided to the participants online. As a preparatory task for the subsequent session, they were asked to reflect upon the mini lessons, paying attention to whether or not learning goals were achieved, and whether or not as many "pupils" as possible were actively involved through heterogeneous-sensitive teaching. Each mini lesson was then re-examined and reflected upon again in the next session. Hence, participants' PV (via teaching video analyses) and their practical teaching competencies (through planning and implementing mini lessons) were to be fostered in successive circles of video production and video reflection.

\subsection{Participants}

A total of 54 students participated in the courses (11 male, 43 female), some of whom had already collected EFL teaching experience as substitute teachers in local schools. All participants aimed at becoming EFL teachers either in primary or secondary schools. Whereas some had only recently begun their studies, others were more ahead. 39 students chose to take part in the study the present article is based upon. Figure 2 provides an overview of these students' language (learning) biographies in terms of the languages represented in the MS development seminars.

As can be seen, 20 students share German as their first language ${ }^{4}$, followed by 8 students who have additional first languages besides German, including Turkish, Spanish, Italian, Vietnamese, and Urdu. One student stated to have three first languages, namely German, Turkish, and Karacay. Ten students reported to have first languages other than German, amongst them Turkish, Farsi, Urdu, Polish, Twi, and Russian. These students had learned German in early childhood during their time in kindergarten and continued doing so in school. Only one student said she had started German later in school. All students had learned at least two foreign languages (FL) in a formal school context. Unsurprisingly, English was the first FL learned by the

4 Due to the sometimes unclear and contradictory associations evoked by terms such as "mother tongue" or "native tongue" (cf. König, 2016), the term "first language" is preferred here to refer to the first language (or languages) acquired in early childhood/during infancy. The term "first foreign language" (FL) is used to describe the first language consciously learned by the child (usually in a formal school context), a language which is not the official one in the respective country. 
Table 2 Participant language (learning) biographies (classification of languages)

\begin{tabular}{|c|c|c|c|c|c|c|}
\hline & L1(s) & $\begin{array}{c}1^{\text {st }} \mathrm{FL} \\
\text { (school) }\end{array}$ & $\begin{array}{c}2^{\text {nd }} \mathrm{FL} \\
\text { (school) }\end{array}$ & $\begin{array}{c}3^{\text {rd }} \mathrm{FL} \\
\text { (school) }\end{array}$ & $\begin{array}{c}4^{\text {th }} \mathrm{FL} \\
\text { (school) }\end{array}$ & $\begin{array}{l}\text { Additional } \\
\text { languages }\end{array}$ \\
\hline German & 20 & & & & & \\
\hline German +1 & 8 & & & & & \\
\hline German +2 & 1 & & & & & \\
\hline $\begin{array}{l}\text { Other than } \\
\text { German }\end{array}$ & 10 & & & & & \\
\hline English & & 35 & 4 & & & \\
\hline Spanish & & 3 & & 10 & 2 & 4 \\
\hline German & & 2 & 1 & & & \\
\hline French & & & 30 & 3 & & \\
\hline Latin & & & 3 & 3 & & \\
\hline Hindi & & & 1 & & & \\
\hline Italian & & & & 1 & & 3 \\
\hline Sanskrit & & & & 1 & & \\
\hline Arabic & & & & & & 2 \\
\hline Greek & & & & & & 1 \\
\hline Polish & & & & & & 1 \\
\hline Dutch & & & & & & 1 \\
\hline Punjabi & & & & & & 1 \\
\hline Portuguese & & & & & & 1 \\
\hline total & 39 & 39 & 39 & 18 & 2 & 14 \\
\hline
\end{tabular}

vast majority, followed by Spanish and German. As for the latter, students indicated that they had begun learning German in kindergarten and continued doing so in primary and secondary school. Only very few students had started learning English as a second FL. Most students took French as a second FL in their educational career, followed by languages such as Latin and, in one case, Hindi.

A total of 14 students reported to have acquired additional languages as young adults rather informally, i.e. due to personal relationships or their cultural background. Students' competencies in these languages ranged from being able to take part in everyday conversations to being capable of writing and reading texts in the specific language.

In terms of official documents and existing research, all participants qualify as being "multilingual" since they are in command of at least two modern languages in addition to their first one (Europäische Kommission, 1996). Put differently, they can "function in two or more languages in conversational interaction" (Wei, 2013, p. 33), albeit with varying degrees of competence. However, partial knowledge of languages does not run counter to "multilingualism", for it has become common ground that it does not require individuals to possess native-like competencies in all 
72 their languages (Europarat, 2001). In fact, cases like this - also referred to as "maximum forms of multilingualism" - are rather the exception than the norm (Bausch, 2016, p. 287; trans.). What is more, students indicated that their competencies do not only vary across languages (no matter whether they had been learned in formal school contexts or acquired more informally), but also throughout time, i.e. they did not consider their language competencies as stable (apart from their L1s and English). Hence, they may be classified as "dominant or asymmetric" multilinguals (Bausch, 2016, p. 287; trans.).

\subsection{Questions and methodology}

Both the insights provided by current research (cf. sections 1 and 2) as well as the rich and diverse language backgrounds represented in the MS seminars brought up the following questions:

1. Do prospective teachers' individual language (learning) biographies have an impact on the development of their PV? What is the nature of this impact?

2. Do prospective teachers' individual language (learning) biographies have an impact on the development of their practical teaching capabilities? What is the nature of this impact?

In methodological terms, self-report questionnaires including two semi-closed questions, two Likert scales and four more open-ended items ${ }^{5}$ (see Dörnyei, 2007) were designed to answer the above questions for they lend themselves well to gain in-depth insights into students' inner perspectives which would otherwise remain largely unobservable (Riemer, 2016). 39 questionnaires were handed in for analysis. Owing to the definition of Professional Vision (section 1.1), items served as indicators of either Professional Vision or practical teaching capabilities. In any case, respondents had to exemplify and explain their answers or choices. Each written explanation was dealt with as a "unit of analysis" (Kuckartz, 2012, p. 30) for inductive category development. ${ }^{6}$ Students' written explanations were summarised and paraphrased, thereby arriving at text-based, abstract categories (Mayring, 2010; cf. section 5.1).

5 The entire questionnaire was comprised of a total of 10 overarching questions (which were subdivided into several more specific questions) on students' language learning biographies and instruments used throughout the seminars. The open-ended questions asked the participants to write full texts, e.g. "Please exemplify and explain your choice made in the Likert item". In the semi-closed questions the students had to tick one of two options. As for the Likert Scales and the closed items, percentages of the options chosen by the participants were calculated.

6 Inductive category development was preferred to a deductive approach due to the explorative nature of the investigation (cf. Kuckartz, 2012). 


\section{The development of Professional Vision (PV) in multilingual-sensitive (MS) classes}

\subsection{Language (learning) biographies and video reflection}

The questionnaire item that addresses the impact LLBs may have on students' reflective competencies/their PV reads as follows:

Have the languages at your disposal played a role when reflecting on the micro-teaching videos?

Out of 29 students who responded to this item, 16 (55.17\%) reported that their languages played a role during video analyses, followed by 13 (44.83\%) students who denied this. Unfortunately, the latter did not put forward any reasons for their choice. The following two comments illustrate how students' general language repertoire assisted them during video reflection 7 :

(1) Since I do not speak many languages, they only assisted my video reflections in limited ways. Despite this, they helped me to make sense of pupils' comments, questions and intentions, and they further enabled me to uncover possible reasons for disturbance and to find ways to address these issues.

(2) My languages frequently helped me to trace back pupils' mistakes and to show pupils ways of how to avoid them in the future.

Both comments exemplify ways in which languages at students' command have assisted video analyses, namely in offering them a deeper understanding of pupils' contributions in class (1) and in putting them in the position to reconstruct pupils' mistakes (2). Neither comment refers to specific languages employed, but the first sentence of comment (1) evokes the assumption that the number of background languages might be of importance in terms of PV development.

As for the question regarding which specific languages were involved in video reflection, students' responses revealed that Romance languages seemed to play a prominent role. More specifically, their explicit knowledge about and implicit knowledge of languages such as French or Spanish enabled them to notice and reflect on multilingual-sensitive teaching and learning situations in the micro-teaching videos:

(3) The connection between the target language, English, and Spanish helped me to deepen my multilingual awareness.

(4)I know Spanish grammar, so I could easily respond to some of the pupils' contributions. I tried to find similarities between languages to ease the teaching and learning of English.

7 Each comment in this article was provided by a different participant. 
74 (5) My language feeling of Romance languages supported video reflection. It helped me to derive the meaning of words unknown to pupils and explain their meaning.

(6) Since I know the grammar of French and Italian, I could foresee which terms and explanations could have helped pupils in a specific situation.

(7) Without my knowledge of Spanish and French it would not have been possible for me to make intelligent guesses about what pupils might think or are about to say in many cases.

As can be seen, students drew on both, their grammatical (4) and lexical (5) language knowledge during video analyses, and their language backgrounds helped them to anticipate and make sense of pupils' contributions and difficulties.

According to some students, their first language(s) served specific purposes during video reflection as well. Unsurprisingly, a number of these students relied on their "intuitive language feeling" rather than explicit structural knowledge in this context, as exemplified in quote (8). However, more explicit knowledge also proved to enhance students' multilingual reflective competencies as illuminated in quotes (9-10):

(8) Due to my intuitive feeling for languages I could defend and justify my performance as a teacher when it was analysed and reflected.

(9) My mother tongue [Farsi] assisted me in understanding Ahmed's and Manisha's ${ }^{8}$ intentions, especially when they lacked English expressions to make meaning because Farsi, Urdu and Arabic share certain similarities.

(10) My knowledge of grammatical and lexical phenomena further enabled me to help pupils such as Ahmed, for instance when he tried to express something in Arabic. Arabic and Turkish share related words, so I could decode lexical items used by Ahmed and translate them into English. This also worked for Marino's 9 Spanish contributions.

(11) I know exactly what it is like to speak a language at home which is different from the surrounding, official language. Besides offering pupils language comparisons, my languages really put me in the position to understand these pupils' feelings.

Numerous statements comparable to comment (11) have been made, including rather emotional aspects students encountered when they had their first language other than German in mind during video reflection. This leads to the second indicator of students' PV development, namely their ability to put themselves into pupils' position, i.e. to empathize with pupils.

8 Ahmed and Manisha are imaginary pupils. As exemplified on the role cards, their first languages are Arabic and Urdu/Hindi/German, respectively.

9 Another imaginary pupil whose first language is Spanish. 


\subsection{Language (Learning) Biographies and Empathy}

The accompanying questionnaire item reads as follows:

My languages helped me to empathize with "pupils".

A total of 39 students responded to the item, 17 (43.59\%) of whom stated that their languages helped them "to a medium extent", followed by $9(23.08 \%)$ students who chose the option "to a high extent", and three participants who opted for "to a very high extent". As for the students who did not agree with the item, 8 (20.51\%) pointed out that their languages helped them "to a rather low extent" and two students $(5.13 \%)$ even claimed that their languages "did not help them at all".

Students' explanations of which languages enabled them to put themselves into the position of "pupils" roles uncover that first languages as well as languages learned in and out of formal school contexts served this purpose alike. Again, utilitarian comments were emphasized, i.e. students used their languages to match with "pupils'" role cards, as the following two statements show:

(1) Spanish helped me to deal with Marino ${ }^{10}$. Without Spanish, this would not have been possible.

(2) German helped me to understand German pupils' syntactic mistakes. Negative transfer resulted in such mistakes.

Interestingly, students ascribed their lack of empathy with "pupils" to the fact that they only speak " $a$ few" languages, and that these languages were not part of any role card:

(3)I only speak English, German and a little Spanish. This did not help me to put myself into Turkish or Arabic pupils.

The mere number of languages spoken by students seemed to play a crucial role in terms of the ability to empathize with "pupils" beyond specific languages, or cross-linguistically, as well:

(4) Since I know four languages, and speak three of them consciously, it was very easy from the beginning to empathize with pupils and their problems. While planning the micro-teaching, I did not focus on one language or the other, but on the general fact that I have to teach a multilingual class.

Students who primarily drew on the languages they had learned in school stressed that these languages enabled them to understand "pupils'" language learning difficulties. In this context, French was amongst the languages most frequently mentioned:

10 Cf. footnote 7. 
76 (5) My French is much worse than my English, however, this assisted me in seeing how complex learning English is for some pupils, because I thought that for some students, learning English is as challenging as learning French was for me.

Besides French, some students referred to the target language English and their first language German in the attempt to "feel what pupils feel when sitting in the classroom":

(6) Just like the pupils, I am still a learner of English myself, since it is not my first language. I also teach German to refugees from Syria, and I know that these people have an entirely different language system. Hence, you cannot expect them to understand metalinguistic grammatical terms, you have to find other ways to explain things.

Whereas students' first language German turned out to be an often used tool to empathize with "pupils" language learning challenges, the absence of German as a first language resulted in slightly different perspectives. In other words, students with first languages other than German reported that they could imagine "what it feels like not to speak the surrounding language fluently" and "how difficult it is for these pupils to raise their hands and participate in class, even if the target language is English and the teacher uses German from time to time to clarify task requirements and the like". Some students further argued that they themselves had experienced "being different" first hand:

(7) My parents only spoke Vietnamese. When I was in school, they couldn't help me and it was very difficult for me to follow what was going on in class because I did not understand all the instructions.

\subsection{Précis}

Given the above considerations, question 1 (section 3.3) may be cautiously answered as follows: A slight majority of students indicated that their languages assisted them in video reflection, which served as an indicator of PV development. The same is true for the second indicator of PV. Here, a more solid majority agreed with the assumption that background languages serve to put students in the position to empathize with pupils. Further, the students' responses suggest that the more languages they have at their command, the richer the language basis they draw upon to develop their PV. 


\section{The development of teaching practices in MS classes}

\subsection{Language (learning) biographies and multilingual-sensitive teaching}

Before students were asked about the impact their own language repertoires might have had on the concrete planning of their microteaching sessions, i.e. their practical competencies, they were to reflect on this issue in a more theoretical sense, as the accompanying questionnaire item illustrates:

In order to respond to/adapt EFL teaching to a multilingual learning group, the teacher should have learned

a) ... as many languages as possible in a formal context (e.g. in school)

b) ... as many languages as possible informally (e.g. through migration)

Out of 39 respondents, 22 (56.41\%) opted for (a), followed by 16 (41.03\%) who opted for (b). Many students emphasized that they found both options useful, and explained their view by offering advantages and disadvantages of both options. However, every student arrived at a clear choice by weighing their arguments. One student $(2.56 \%)$ stated that according to him, neither option plays a role.

The arguments put forward by the students who supported teachers' formal language learning biographies may be put into three main categories, namely "thoroughness of language knowledge", "transfer of language learning experiences" and “language-specific arguments", graded by the number of students' references, respectively. ${ }^{11}$

As for the first category, students frequently emphasized that in formal school contexts, grammatical language items are learned "strategically", "systematically" and "consciously" which is why teachers who have learned languages this way are "later able to explain differences between languages in a correct and factual manner". Within the second category, students expressed their conviction that "teachers draw on their own school experiences to understand pupils' problems". More precisely, it was argued that "teachers remember the teaching methods by which they were taught, and they can apply these methods in their own teaching later", and, further, that "these teachers know what it is like to learn a new language from the start in school". The third category subsumes arguments more utilitarian in nature, i.e. they refer to the specific languages teachers have at their command due to formal school education. These languages include, according to students, French and Spanish, which allow teachers to offer their pupils "language comparisons" for "these teachers have learned the same languages at school as their pupils have to learn now".

To a certain extent, the arguments put forward by students who opted for version (b) of the questionnaire item fit the above categories, albeit with differences

11 As suggested by Mayring (2010), careful attention was paid to the level of category abstraction, i.e. it was ensured via repeated data analyses that the categories still reflect what was actually written by students. 
78 in terms of content and prioritization: Students' comments which may be subsumed under the category "transfer of language learning experiences" were the most frequently mentioned. What is more, an emotional component was included in the statements provided by the students who opted for option (b), which was missing in the ones put forward by the students who opted for option (a) (cf. comment 3 below). The students who opted for option (b) found teachers' informal language learning biographies more useful than formal ones to adapt EFL teaching to multilingual learning groups:

(1) Teachers with a migration background may act as role models for their pupils, especially because they know about specific culture-related behaviour.

(2) Pupils who share a migration background with the teacher can identify themselves with the teacher. In addition, these teachers know how it feels not to speak the official language well and what it is like to speak different languages in school and at home.

(3)I know from experience that pupils with a migrant background respect immigrant teachers. They have a strong emotional bond.

"Language-specific arguments" clustered around languages such as Arabic or Turkish. It is assumed here that these languages are generally associated with immigrant teachers and pupils in Germany, a premise also reflected in students' comments who argued that "the number of pupils with a migrant background increases, and most of them speak Arabic or Turkish. Teachers who speak these languages are better able to understand these pupils' thoughts".

Albeit arguments falling into the third category, "thoroughness of language knowledge", were relatively few in number, they offer interesting insights into what kind of language knowledge, according to students, might assist teachers who have acquired languages informally in responding to multilingual EFL learning groups. As one student put it: "Teachers who have learned their languages out of school are probably more sensitive to pragmatic language aspects than teachers who have learned languages in formal contexts only. Hence the former are maybe less able to explain grammatical rules, but outperform the latter in terms of showing pupils pragmatics".

\subsection{Language (learning) biographies and multilingual-sensitive learning tasks}

To gain insights into the impact students' LLBs had on the concrete planning of their mini lessons, the following questionnaire item was formulated:

My languages helped me to design appropriate learning tasks for multilingual "pupils".

From the 39 students who responded to this item, 14 (35.90\%) agreed that their languages had helped them "to a medium extent", followed by $5(12.82 \%)$ who chose 
"to a high extent" and 1 (2.56\%) who opted for "to a very high extent". A number of students not to be underestimated (a total of $48.71 \%$ ) stated that their languages only helped them to design learning tasks "to a rather low extent" (13 students, $33.33 \%$ ) or "not at all" (6 students, 15.38\%).

Students who agreed that their languages had helped them to develop appropriate learning tasks predominantly argued that Romance languages learned at school put them in the position to design tasks which explicitly focus on language comparison, thereby having "pupils" being actively involved in finding grammatical and lexical contrast and similarities between related languages. Other languages such as Turkish or Arabic led students to think of tasks which underline phonological similarities of languages so that "pupils" may use these similarities to understand English texts.

Many comments went beyond the design of specific learning tasks and included aspects such as classroom management (1) and learning assistance $(2,3)$ :

(1) Because of my languages, I knew which pupils could help each other during task performance. This helped me when I made the seating plan. .

(2) My languages helped me to individualise tasks and to develop learning aids for pupils. For example, we designed a vocabulary sheet for Ahmed ${ }^{12}$ and provided electronic dictionaries for non-German pupils.

(3)I learned from the other group members, who speak languages such as Turkish or Arabic, that some pupils have a writing system different from ours. It was also easier to estimate how difficult a task would be for pupils with a non-European background.

The fact that students planned the micro-teachings in groups turned out to be useful: This way, students had access to their group members' languages in addition to their own ones, as shown in statement (3).

The arguments put forward by students who rather denied their languages to have played a significant role when designing language learning tasks cluster around three major aspects. First and foremost, students argued that they "were not competent enough" in their additional languages to employ them as resources for task development. Second, students emphasized that neither themselves nor their group members were in command of languages represented by the "pupils", i.e. by the role cards, such as Turkish, Arabic or Polish. Third, the scarce use of languages for task development was explained by the fact that "the chosen content of the lesson did not lend itself to multilingual-sensitive teaching".

\subsection{Précis}

In terms of question 2 (section 3.3), students' answers to the questionnaire item which served as an indicator of students' multilingual-sensitive practical teaching

12 Cf. footnote 6 . 
80 capabilities reveal that a narrow majority found their languages useful to design appropriate learning tasks for multilingual pupils. Quite a number of statements put forward by students who denied their languages as a positive role in designing multilingual-sensitive learning tasks hinted at their lack of knowledge of specific languages to be one of the reasons for this: according to students' comments, they found themselves unable to develop multilingual-sensitive tasks because they were not in command of languages represented by their pupils, i.e, they did not speak "enough" languages. This may lead to the suggestion that the more languages students have at their command, the richer the language basis they draw upon to develop their practical teaching capabilities. Students' comments were very straightforward here since they suggest that the "richness" of their language basis is to be understood as a 1:1 match of languages spoken by pupils and the teacher. If, however, this "richness" is perceived as a more cross-linguistic or meta-linguistic multilingual awareness evolving from the existence of a critical number of languages in students' repertoire, it has to be pointed out that no student referred to such a kind of awareness.

\section{Summary and discussion of findings}

The reflections the present article is based upon aimed primarily at gaining explorative insights into the development of pre-service EFL teachers' Professional Vision (PV) and practical teaching competencies in video-based, multilingual-sensitive (MS) classes. In this context, it was to be investigated whether students' individual language (learning) biographies (LLBs) have an impact on the development of their PV and practical teaching competencies. The elaborations made throughout this article allow for tentative answers.

As for question one, it is safe to say at this point that students' LLBs had a positive impact on the development of their PV. When engaged in video reflection, students drew on their languages to arrive at a deeper understanding of pupils' contributions. The reported ability to reconstruct and predict EFL learners' mistakes and potential learning difficulties mirrors findings from earlier research (Ellis, 2004; Garvey \& Murray, 2004). Concerning the nature of the impact students' LLBs have on their PV, it has become obvious that students employ their implicit knowledge of, as well as explicit knowledge about languages they have learned in school or - if that was the case - acquired in more informal learning contexts. Formally learned languages enabled students to arrive at a deep understanding of pupils' learning difficulties, partly because students were familiar with formal school settings and partly because they had all learned English as a foreign language themselves.

Romance languages fostered students' awareness of language similarities which, according to students, can be exploited to facilitate pupils' EFL learning. Students also relied on their first languages during video analyses, especially if these L1s were languages other than German. The use of first languages other than German clearly went beyond linguistic aspects such as language comparisons. Emotional aspects 
were covered as well. More precisely, students' first languages enabled them to understand pupils' feelings of "otherness" and accompanying difficulties such as a lack of understanding of teachers' instructions and task requirements, a finding clearly in line with Safford and Kelly's notion of “mirror participants” (Safford \& Kelly, 2010). Another finding that supports existing research is namely the fact that the number of languages at a student's command seems to determine their PV development (cf. Otwinowska, 2014).

Regarding question two, it has become obvious that, although a slight majority of students employed their school languages to uncover language contrasts and similarities and their home languages to adopt learning tasks to various students' needs, those students who felt unable to use their languages to design multilingual-sensitive learning tasks ascribed this to their lack of competency in specific languages. Again, Otwinowska's findings are supported here (cf. Otwinowska, 2014).

Throughout the entirety of students' remarks and comments, a certain dependency on specific languages was noticed, i.e. the view that only a match between their own and pupils' languages enables them to develop PV and practical teaching competencies. To overcome such rather shortsighted positions it is up to teacher educators to find ways of how students may develop a meta- or cross-linguistic awareness of multilingualism that will enable the teacher to plan, implement and reflect upon multilingual-sensitive EFL teaching without having competencies in all the languages represented in a specific classroom (especially languages which are typologically distant from the target language English and the surrounding, official language). Cooperative activities of teachers who are in command of a wide array of languages are a step into the right direction, but more theory-based and conceptual frameworks have to be developed as well.

The present reflection is subject to various limitations: Although the theoretically-driven conception of Professional Vision (section 1) suggests that pre-service teachers" "video reflection" and their "empathy with pupils" may serve as appropriate indicators of Professional Vision, this has not been empirically proven. Future research needs to examine to what extent both indicators qualify as reliable aspects of the construct of PV. Further, students' written comments should be revisited in follow-up interviews to consolidate their meaning, and to extend the knowledge about the relation between LLBs and PV development.

Another limitation which has to be addressed is the way the data collected was analysed. As mentioned in section 3.3, students' written questionnaire responses were collected, ordered and interpreted inductively to find similarities and contrasts between students' statements. Although this approach allows for insights highly explorative in nature, it cannot replace more systematic investigations suggested by content analysis (Kuckartz, 2012; Mayring, 2010). Still, the findings obtained can be used to inform further research in such a way as to provide a basis for the development of categories which, in turn, allow for more quantitative insights into the role pre-service teachers' LLBs play in the development of their PV and practical teaching capabilities. 
Finally, the context within which the students who responded to the questionnaires produced and analysed teaching videos was a highly artificial one, particularly since students played "pupils" according to pre-designed role cards. It remains to be seen whether the findings made here maintain in authentic learning contexts.

\section{References}

Abney, S., \& Krulatz, A. (2015). Fostering multilingual competence in the EFL classroom. Nordic Journal of Modern Language Methodology, 3(2), 1-9.

Amin, N. (2001). Nativism, the native speaker construct, and minority immigrant women teachers of English as a second language. The CATESOL Journal, 13(1), 89-107.

Baecher, L., Kung, S.-C., Jewkes, A. M., \& Rosalia, C. (2013). The role of video for self-evaluation in early field experiences. Teaching and Teacher Education, 36, 189-197.

Banks, J., Cochran-Smith, M., Moll, L., Richert, A., Zeichner, K., LePage, P., Darling-Hammond, L., Duffy, H., \& McDonald, M. (2005). Teaching diverse learners. In L. Darling-Hammond \& J. Bransford (Eds.). Preparing Teachers for a Changing World. What Teachers Should Learn and Be Able to Do (pp. 232-274). San Francisco, CA: John Wiley.

Bausch, K. R. (2016). Formen von Zwei- und Mehrsprachigkeit. In E. Burwitz-Melzer, G. Mehlhorn, C. Riemer, K. R. Bausch \& H. J. Krumm (Eds.), Handbuch Fremdsprachenunterricht (pp. 285-290). Tübingen: Francke.

Borko, H., Jacobs, J., Eiteljorg, E., \& Pittman, M. E. (2008). Video as a tool for fostering productive discussions in mathematics professional development. Teaching and Teacher Education, 24(2), 417-436.

Brophy, J. E. (Ed.). (2004). Using video in teacher education. Amsterdam: JAI.

Cenoz, J., \& Gorter, D. (Eds.). (2014). Multilingual education: Between language learning and translanguanging. Cambridge: Cambridge University Press.

Cummins, J. (2005). Teaching for cross-language transfer in dual language education - possibilities and pitfalls. Retrieved from http://www.tesol.org/docs/default-source/new -resource-library/symposium-on-dual-language-education-3.pdf?sfvrsn=0

Clyne, M. (2008). The monolingual mindset as an impediment to the development of plurilingual potential in Australia. Sociolinguistic Studies, 2(3), 347-366.

Conteh, J., \& Meier, G. (Eds.). (2014). The multilingual turn in languages education. Opportunities and challenges. Multilingual Matters.

Dörnyei, Z. (2007). Research methods in applied linguistics. Oxford: Oxford University Press.

Ellis, L. (2002). Teaching from experience: A new perspective on the non-native teacher in adult ESL. Australian Review of Applied Linguistics, 25(1), 71-107.

Ellis, M. (2004). The invisible multilingual teacher: the contribution of language background to Australian ESL teachers' professional knowledge and beliefs. The International Journal of Multilingualism, 1(2), 90-107.

Europäische Kommission (Ed.). (1996). Weißbuch zur allgemeinen und beruflichen Bildung: Lehren und lernen auf dem Weg zur kognitiven Gesellschaft. Luxemburg.

Europarat (2001). Gemeinsamer Europäischer Referenzrahmen für Sprachen. Lernen, Lehren, Beurteilen. Berlin: Langenscheidt.

European Commission (2015). Language teaching and learning in multilingual classrooms. Luxembourg: Publications Office of the European Union.

Farrell, T. (1998). Principles and practices of reflective teaching. English Teaching Forum, 3, 10-17.

Frederiksen, J. R., Sipusic, M., Sherin, M. G., \& Wolfe, E. (1998). Video portfolio assessment: Creating a framework for viewing the functions of teaching. Educational Assessment, 5(4), 225-297.

Garvey, E., \& Murray, D. (2004). The multilingual teacher: Issues for teacher education. Prospect, 19(2), 3-24. 
Goodwin, C. (1994). Professional Vision. American Anthropologist, 96(3), 606-655.

Hellermann, C. Gold, B., \& Holodynski, M. (2015). Förderung von Klassenführungsfähigkeiten im Lehramtsstudium. Zeitschrift für Entwicklungspsychologie und Pädagogische Psychologie, 47(2), 97-109.

Hufeisen, B., \& Neuner, G. (2005). Mehrsprachigkeitskonzept - Tertiärsprachenlernen Deutsch nach Englisch. Straßburg: Europarat.

Jacobs, J. K., \& Morita, E. (2002). Japanese and American teachers' evaluations of videotaped mathematics lessons. Journal for Research in Mathematics Education, 33(3), 154-175.

Jessner, U. (2006). Linguistic awareness in multilinguals. Edinburgh University Press.

Kleinknecht, M. \& Schneider, J. (2013). What do teachers think and feel when analysing videos of themselves and other teachers teaching? Teaching and Teacher Education, 33, 13-23.

Kleinknecht, M., Schneider, J., \& Syring, M. (2014). Varianten videobasierten Lehrens und Lernens in der Lehrpersonenaus- und -fortbildung - Empirische Befunde und didaktische Empfehlungen zum Einsatz unterschiedlicher Lehr-Lern-Konzepte und Videotypen. Beiträge zur Lehrerinnen - und Lehrerbildung, 32(2), 210-220.

König, K. (2016). Erstsprache - Herkunftssprache - Muttersprache. Sprachbiographische Zugänge von Deutsch-TürkInnen auf den Ausdruck Muttersprache. In M. Raml (Ed.). Wanderer zwischen den Welten. Deutsch-türkische Sprachbiographien (pp. 269-294). Würzburg: Königshausen \& Neumann.

Krammer, K. , \& Hugener, I. (2014). Förderung der Analysekompetenz angehender Lehrpersonen anhand von eigenen und fremden Unterrichtsvideos. Journal für Lehrerinnenbildung, 1, 25-32.

Kuckartz, U. (2012). Qualitative Inhaltsanalyse. Methoden, Praxis, Computerunterstützung. Weinheim: Beltz Juventa.

Lightbown, P. M., \& Spada, N. (2013). How languages are learned. Oxford, UK: Oxford University Press.

Lortie, D. (1975). Schoolteacher: A sociological study. Chicago: University of Chicago Press.

May, S. (Ed.). (2014). The multilingual turn. Implications for SLA, TESOL and bilingual education. Routledge.

Mayring, P. (2010). Qualitative Inhaltsanalyse. Grundlagen und Techniken. Weinheim: Beltz.

Milambiling, J. (2011). Bringing one language to another: Multilingualism as a resource in the language classroom. English Teaching Forum, 49(1), 18-35.

Moloney, R., \& Giles, A. (2015). Plurilingual pre-service teachers in a multicultural society: Insightful, invaluable, invisible. Australian Review of Applied Linguistics, 38(3), 123-138.

Otwinowska, A. (2014). Does multilingualism influence plurilingual awareness of Polish teachers of English? International Journal of Multilingualism, 11(1), 97-119.

Reed, Y., Davis, H., \& Nyabanyaba, T. (2002). Investigating teachers' 'take up' of reflective practice from an In-service professional development teacher education programme in South Africa. Educational Action Research, 10(2), 253-274.

Riemer, C. (2016). Befragung. In D. Caspari, F. Klippel, M. K. Legutke \& K. Schramm (Eds.). Forschungsmethoden in der Fremdsprachendidaktik (pp. 155-173). Tübingen: Narr Francke Attempto.

Rosaen, C. L., Lundeberg, M., Cooper, M., Fritzen, A., \& Terpstra, M. (2008). Noticing. How does investigation of video records change how teachers reflect on their practices? Journal of Teacher Education, 59(4), 347-360.

Safford, K., \& Kelly, A. (2010). Linguistic capital of trainee teachers: Knowledge worth having? Language and Education, 24(5), 401-414.

Schecter, S. R. \& Cummins, J. (Eds.). (2003). Multilingual education in practice. Portsmouth, N. H.: Heinemann.

Schön, D. (1983). The reflective practitioner. NY: Basic Books, Inc.

Seidel, T., Stürmer, K., Blomberg, G., Kobarg, M., \& Schwindt, K. (2011). Teacher learning from analysis of videotaped classroom situations: Does it make a difference whether teachers observe their own teaching or that of others? Teaching and Teacher Education, 27(2), 259-267. 
84 Sherin, M. G. (2004). New perspectives on the role of video in teacher education. In J. Brophy (Ed.). Advances in Research on Teaching. Vol 10. Using Video in Teacher Education (pp. 1-27). Oxford, UK: Elsevier.

Sherin, M. G. (2007). The development of teachers' professional vision in video clubs. In R. Goldman, R. Pea, B. Barron and S. Derry (Eds.). Video Research in the Learning Sciences (pp. 383-395). Mahwah, NJ: Erlbaum.

Sherin, M. G., \& Han, S. Y. (2004). Teacher learning in the context of a video club. Teaching and Teacher Education, 20(2), 163-183.

Sherin, M. G., Russ, R., Sherin, B. L. \& Colestock, A. (2008). Professional vision in action: An exploratory study. Issues in Teacher Education, 17(2), 27-46.

Sherin, M. G., \& van Es, E. A. (2002). Using video to support teachers' ability to interpret classroom interactions. Proceedings of the $13^{\text {th }}$ annual meeting of the society for information technology and teacher education (pp. 2532-2536). Norfolk, VA: Association for the Advancement of Computing in Education.

Sherin, M. G., \& van Es, E. A. (2009) Effects of video club participation on teachers' professional vision. Journal of Teacher Education, 60(1), 20-37.

Trautmann, M. (2010). Heterogenität - (k)ein Thema der Fremdsprachendidaktik? In A. Köker, S. Romahn, \& A. Textor (Eds). Herausforderung Heterogenität - Ansätze und Weichenstellungen (pp. 52-64). Bad Heilbrunn: Klinkhardt.

Trautmann, M., \& Wischer, B. (2011). Heterogenität in der Schule. Eine kritische Einführung. Wiesbaden: VS Verlag.

Van Es, E.A., \& Sherin, M.G. (2008). Mathematics teachers' "learning to notice" in the context of a video club. Teaching and Teacher Education, 24(2), 244-276.

Wallace, M.J. (1991). Training foreign language teachers: A reflective approach. Cambridge: Cambridge University Press.

Wei, L. (2013). Conceptual and methodological issues in bilingualism and multilingualism research. In T. K. Bhatia \& C. Ritchie (Eds.). The Handbook of Bilingualism and Multilingualism (pp. 26-51). Oxford: Wiley Blackwell.

Zeichner, K. M., \& Liston, D. P. (1987). Teaching student teachers to reflect. Harvard Educational Research Journal, 57(1), 22-48.

Zhang, M., Lundeberg, M., Koehler, M. J., \& Eberhardt, J. (2011). Understanding affordances and challenges of three types of video for teacher professional development. Teaching and Teacher Education, 27(2), 454-462.

Ziegler, G. (2013). Multilingualism and the language education landscape: Challenges for teacher training in Europe. Multilingual Education, 3(1), 1-23.

Dr. Heike Niesen

Department of English and American Studies, Goethe University Frankfurt/Main, Norbert-Wollheim-Platz 1, Frankfurt/Main 60323, Germany Niesen@em.uni-frankfurt.de 